\title{
Effect of Different Types of Fertilization on Vigna unguiculata subsp. sesquipedalis Crop
}

\author{
Christina ANGELI ${ }^{1}$, NikolinaCHEIMONA ${ }^{1}$, Ioanna KAKABOUKI ${ }^{1}$, Charis-Konstantina KONTOPOULOU ${ }^{1}$, \\ Ioanna TABAXI ${ }^{1}$, Anastasia PAPANDREOU ${ }^{1}$, VasIliki PACHI ${ }^{1}$, Ioulia DROSSINOU ${ }^{2}$, Panayiota \\ PAPASTYLIANOU ${ }^{1} \&$ Dimitrios BILALIS ${ }^{1 *}$
}

${ }^{1}$ Agricultural University of Athens, Department of Crop Science, Iera Odos 75, 11855 Athens, Greece.

${ }^{2}$ "Captain Vassilis" Foundation, Athens, Greece

*)Corresponding author, e-mail: bilalisdimitrios@yahoo.gr

BulletinUASVM Horticulture 73(2) / 2016

Print ISSN 1843-5254, Electronic ISSN 1843-5394

DOI:10.15835/buasvmcn-hort:12390

\begin{abstract}
A field experiment was conducted at Pylos, Greece to compare the effect of different types of fertilization on yardlong bean (Vigna unguiculata subsp. sesquipedalis) crop. The conventional treatment plots were fertilized with an inorganic fertilizer, whereas the organic treatments plots received organic compost. Data analysis confirmed no significant correlation between plant height and type of fertilization, but there was significant correlation between length of pods and type of fertilization. In particular, morphological characteristics of yardlong bean were enhanced by inorganic fertilization in comparison with the organic fertilization. Organic farming increased significantly the number on root nodules in comparison with conventional farming.
\end{abstract}

Keywords: compost, landraces, plant growth, Vigna unguiculata ssp. sesquipedalis

\section{Introduction}

The genus Vigna currently includes around 80 species. Cowpea (Vigna unguiculata (L.) Walp.) is an important legume of the tropics, with its various uses: as grains in processed foods, as a vegetable (fresh leaves, peas, and pods), and as dry haulms and fodder. It is an inexpensive source of vegetable protein, and a hardy crop well adapted to relatively dry environments. In combination or association with cereals and other grain legumes, it contributes to the sustainability of cropping systems in marginal lands of semiarid areas, with its fixation of nitrogen, ground cover, and the soil improvement it provides from plant residues (Singh et al., 1997). Yardlong bean (Vigna unguiculata ssp. sesquipedalis (L.) Verdc.) is known as vegetable cowpea, asparagus bean, string bean, snake bean, snake pea, snap pea, bodi, bora and sitao. Its origin is possibly in the Middle West Africa or in Southern China. Yardlong bean is widely grown in Southeast Asia, South China and West Africa for immature pods which are used as a vegetable (Fana et al., 2004). It constitutes also a
Messinian crop landrace in Greece. The aim of this study is to evaluate the effect of organic fertilized on yardlong bean crop.

\section{Materials and methods}

A yardlong bean crop was established in the experimental field of Costa Navarino located in Pylos town in Messinia, Peloponnese, Greece. The experiment was set up according to the randomized complete block design with nine replicates and three treatments: compost, inorganic fertilizer and untreated (control). The field was sowed on 14th of April 2016. Morphological characteristics (plant height, length and weight of pods, number of seeds per pod, weight of 1000 seeds) of yardlong bean were measured. Inflorescence per plant and colonization of roots by arbuscular mycorrhizal fungi were also measured.

\section{Results and discussion}

Morphological characteristics of yardlong bean were enhanced by inorganic fertilization in comparison with the organic fertilization. Data analysis confirmed no significant differences (at $\mathrm{p}<0.05$ ) between plant height and type of 


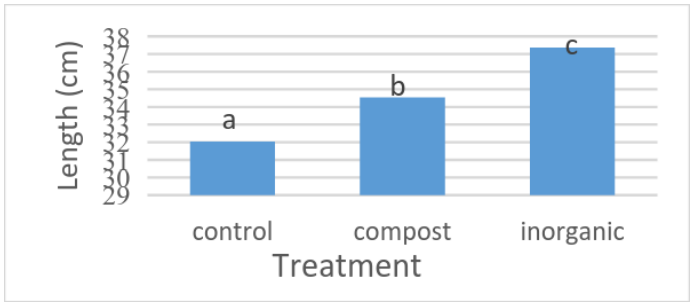

Fig. 1. Average pods of yardlong bean.

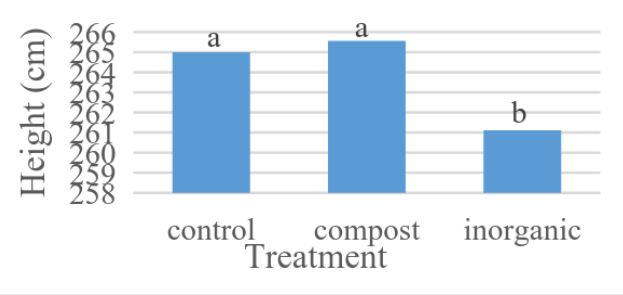

Fig. 2. Average height of yardlong bean.

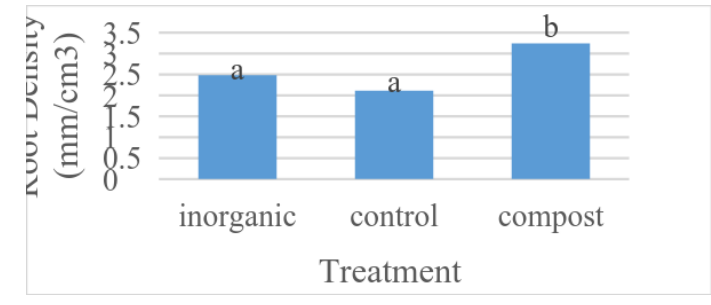

Fig. 3. Root density of yardlong bean.

fertilization (Fig. 2). But was found significant differences (at $\mathrm{p}<0.05)$ between length of pods and type of fertilization was found (Fig. 1). Moreover, root density was significantly higher in organic fertilized plots according LSD-test for significant level 5\% (Fig. 3.). Our results are according with previous study Benchasri and Bairaman (2010).

\section{Conclusion}

In the presentresearch work, we demonstrated the significant role of organic fertilization in yardlong bean's growth. It has to be noted that morphological characteristics were enhanced in inorganic fertilization, probably cause of this effect may rely on the fact that the field had not been cultivated in the previous years.

\section{REFERENCES}

1. Benchasri S. and Bairaman (2010). Evaluation of yield, yield components and consumers' satisfaction towards yardlong bean and cowpea in agricultural organic system. Bulgarian Journal of Agricultural Science 16 (No 6) 2010, 705-712.

2. Fana, S.B., Pasquet, R.S. and Gepts, P. (2004). Genetic diversity in cowpea [Vigna unguiculata (L.) Walp.] as revealed by RAPD markers. Genetic Resources and Crop Evolution. 51: 539-550.

3. Singh, B.B., Mohan Raj, D.R., Dashiell, K.E., and Jackai, L.E.N. (eds) (1997). Advances in Cowpea Research. Copublication Intl Tropical Agric (IITA) and Japan Intl Res Center Agric Sci (JIRCAS) . Sayce, Devon, UK. 